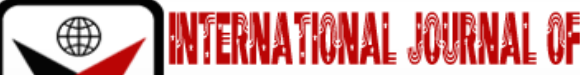

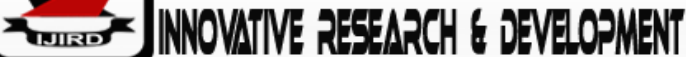

ISSN 2278 - 0211 (Online)

\section{Right to Development Treaties: Nature, Challenges and Prospects}

\author{
Dr. Fasilat Abimbola Olalere \\ Lecturer, Department of Public Law, Elizade University, Ilaramokin, Ondo State, Nigeria
}

\begin{abstract}
:
This paper considered the right to development as a body of rights that have gained recognition and expression in international legal instruments. Specifically, it attempts to conceptualise and examine the nature, scope and application of the right to development. The main aim was to recognize the international treaties at the United Nations and regional international level. At the municipal level, particularly in the case of Nigeria the focus has been placed. The paper concludes that the realisation of the right to development.
\end{abstract}

Keywords: Development, Right to development, universal declaration of human rights, enforceability

\section{Introduction}

In the $21^{\text {st }}$ Century, states have continued to be categorised on the basis of development. While some are regarded as developed, the others are regarded as less developed, underdeveloped or developing. Majority of the African and Asian Countries fall under the latter category.

The drive by developing countries to develop to the globally accepted level as modelled by the developed Western industrialised countries has given rise to agitation for development. Several supra-national regimes both at the universal, regional and sub-regional level have arisen to recognise and give effect to the right to development (RTD). In some climes, this right has also been recognised at the municipal level.

Although vastly recognised by virtually all the nations of the world, the conceptualisation and application of RTD is still a subject matter of divergent perception. States have failed to come to a consensus on these points. These issues are embedded in the various international instruments and treaties in this regard which we shall examine in the course of this work.

\section{Evolution, Nature and Scope of the Right to Development}

'The right to development is the right of peoples and individuals to the constant improvement of their well-being and to a national and global enabling environment conducive to just, equitable, participatory, and human-centred development respectful of all human rights.' ${ }^{1}$ RTD has been viewed to encompass economic, social, cultural and political dimension. This supports the United Nation Commission on Environment and Development (UNCED) position that environment, economic and social development must be considered conjunctively and not in isolation. This is in line with Earth Summit Declaration of Rio wherein fundamental principles upon which nations must anchor their future decisions and policies, considering both environmental and socio-economic implications of development. ${ }^{2}$

Article 1 UN Declaration on the Right to Development provides thus:

- The right to development is an inalienable human right

- The human right to development also implies the full realization of the right of peoples to self-determination.

\section{International Regimes on the Right to Development}

\subsection{The United Nations}

At the level of the United Nations, there have been numerous efforts and tools forming and distinguishing RTD. Although the UN Declaration of 1986 is not on its own a legally binding instrument, however, many of its provisions are also provided for in legally binding instruments, such as the United Nations Charter and the International Covenants on Human Rights, and principles like non-discrimination and State sovereignty which are part of customary international law and binding on all States. ${ }^{3}$

\footnotetext{
${ }^{1}$ McInerney-Lankford, S. and Human, H. S. 2010. Rights Indicators in Development: An introduction. World Bank Study p. 66. Retrieved on the 16th January, 2018 from: siteresources.worldbank.org/EXTLAWJUSTICE/.../HumanRightsWP10_Final.pdf

${ }^{2}$ The Rio Declaration on Environment and Development (1992). Retrieved on the 16 $6^{\text {th }}$ January, 2018 from: www.unesco.org/education/pdf/RIO_E.PDF ${ }^{3}$ United Nations High Commissioner for Human Rights. 2016. Frequently Asked Questions on the Right to Development Fact Sheet No. 37. p. 5. Retrieved on 16 $6^{\text {th }}$ January, 2018 from: www.ohchr.org/Documents/Publications/FSheet37_RtD_EN.pdf
} 
The International Covenant on Economic, Social and Cultural Rights (ICESCR) and the International Covenant on Civil and Political Rights (ICCPR), further expands the scope of RTD provided in the Universal Declaration. The ICCPR has an optional Protocol. The optional protocol is of binding effect on signatory state parties to the protocol.

It is mandated to amongst other things, perform the following functions:

- To monitor and review progress made in the promotion and implementation of the right to development;

- To review reports and any other information submitted; and

- To present for the consideration of the hrc a sessional report on its deliberations.

UN agencies and international institutions such as the United Nations Development Programme (UNDP), United Nations Conference on Trade and Development (UNCTAD), United Nations Framework Convention on Climate Change (UNFCCC), the World Bank, International Monetary Fund (IMF), World Trade Organisation (WTO), United Nations Educational, Scientific and Cultural Organization (UNESCO), World Intellectual Property Organisation (WIPO), World Health Organisation (WHO), the Global Fund etc are as well involved in the work of human rights and development. 4

Another significant UN instrument is the Declaration on the Rights of Indigenous Peoples. Its preamble acknowledges the historic injustices suffered by Indigenous peoples who have been prevented from fully exercising their right to development. Article 23 provides that Indigenous peoples are entitled to determine and develop their own priorities and strategies for exercising this important right. Article 20 provides that Indigenous peoples have the right to freely engage in and develop, among other things, their traditional and other economic activities, and that Indigenous peoples deprived of their means of subsistence and development are entitled to redress.

Several articles of the Declaration deal with the rights of Indigenous peoples in relation to specific cultural issues. ${ }^{5}$ The most prominent of right reposed on indigenous groups is contained in Article 23 which recognises their right to determine and develop priorities and strategies for exercising their right to development. Similar provision is contained in Article 7 International Labour Organisation (ILO) Convention concerning Indigenous and Tribal Peoples in Independent Countries of 1989 with the additional clause- 'to the extent possible'. In the Yatama case, it was held that Nicaragua has the obligation to 'adopt all necessary measures to ensure that the members of the indigenous and ethnic communities of the Atlantic Coast of Nicaragua can equally participate, in decision-making on matters and policies that affect or could affect their rights and the development of these communities'. ${ }^{6}$

\section{Regional Regimes on the Right to Development}

\subsection{Organisation of American States}

The Charter of the Organisation of American States 1948 provides in details the concept, rights and duties of integral development. The underlining goal according to Article 33 is to ensure the 'establishment of a more just economic and social order that will make possible and contribute to the fulfilment of the individual'. Article 31 imposes integral development as the common and joint responsibility of member States, preferably through multilateral organisations. ${ }^{7}$ Cooperation among States in this regard should be in the form of economic, social, educational, cultural, scientific and technological fields. It also called for support in the achievement of national objectives of the Member States and mutual respect for the developmental priorities of each country without any political ties or conditions.

Article 17 of the Charter provides that 'each state has the right to develop its cultural, political and economic life freely and naturally'. Particularly, Article 10 provides that 'states are juridically equal, enjoy equal rights and equal capacity to exercise those rights, and have equal duties'. Article 11 establishes that 'every American state has the duty to respect the rights enjoyed by every other state in accordance with international law'. Article 30 further states that international social justice and integral development are essential conditions to peace and security. Clearly, peace and security are not dependable on any one state by itself. Be that as it may, the conditions for achieving peace and security involve a collective responsibility to be performed by all Member States.

On a close examination of Article 17 and Chapter VII of the Charter, one can safely conclude that the Charter does not clearly establish individual's right to development. Development is seen as more or less a means to the self-fulfilment of the individual. While Article 17 establishes the right of states to develop their cultural, political and economic life freely and naturally, it appears nothing therein seem to give an indication of integral development, which happens to be the central theme of that chapter. ${ }^{8}$

\subsection{League of Arab States}

The Arab Charter on Human Rights 2004 recognises RTD as a fundamental human right and all State parties are obligated to establish their development policies and to take the required measures to guarantee this right. ${ }^{9}$

\subsection{Association of Southeast Asian Nations (ASEAN)}

A section of the ASEAN Human Rights Declaration of 2012 is concerned and devoted to RTD.

\section{4ibid.}

${ }^{5}$ Articles 12-16, 23 and 24

${ }^{6}$ Kingsbury B. 2011.Indigenous peoples. p. 15. Retrieved on $16^{\text {th }}$ January, 2018 from: iilj.org/wp-content/uploads/2016/08/Kingsbury-Indigenous-Peoples1.pdf

${ }^{7}$ Article 32

${ }^{8}$ Negro, D. M. 2008. Article 17 and Chapter VII of the revised OAS Charter and relevant experience of OAS institutions. In Marks, S. P. (Ed.) Implementing the Right to Development: The Role of International Law. Geneva: Friedrich-Ebert-Stiftung. p. 69.

${ }^{9}$ See, Article 37 


\subsection{African Union}

The African Charter on Human and Peoples' Rights 1981 is a legally binding treaty between the 53 African State parties, which forms the African Union. The charter provides that: 'All peoples shall have the right to their economic, social and cultural development. ${ }^{10}$ Similar provisions are contained for specific groups in the African Youth Charter ${ }^{11}$ and in the Protocol to the African Charter on Human and Peoples'12

Article 26 deals with implementation and monitoring of the protocol and the responsibility of state parties thereto.

The express recognition of RTD gave impetus to the Ogoni and Endoroi's Cases brought before the African Commission on Human Right. The Commission actually upheld the RTD in those cases. It is however noted that, the Bakweri Land Claims Case, was the only case where the African Commission was seized with a communication explicitly based on Article 22. The claims of the complainants that the concentration of their historic lands in non-native hands by the government was alleged to have violated their RTD as contained in Article $22 .{ }^{13}$ However, the matter did not go beyond the preliminary stage.

In the Endorois case, the Commission found out that the Kenyan government had violated the right to development of the Endorois people for its failure to consult and to ensure participation of the complainants in the relevant decision-making processes and lack of equity in the distribution of the benefits of development. The Endorois community consist of approximately 60,000 people who have lived around Lake Bogoria in the Rift Valley for centuries. In 1978, the Government created the Lake Bogoria Game Reserve, excluding the Endorois from their traditional lands and grazing pastures, which resulted in the deaths of large numbers of their cattle, the community's livelihood. With reference to the Declaration on the Right to Development and the United Nations Declaration on the Rights of Indigenous Peoples, the Commission, found for the Endorois people that they have been dispossessed of their traditional lands and denied access to resources in a manner that constitutes a violation of their right to development. According to the Commission, the failure to provide adequate compensation and benefits, or provide suitable land for grazing indicates that the Respondent State did not adequately provide for the Endorois in the development process.

\section{Challenges of Right to Development Treaties}

The RTD is vastly recognised by many states of the world, howbeit, in varying degrees. The views of States are still divided on this point. There is lack of consensus on its conceptualisation, political and strategic challenges to the practical implementation of the RTD. Some countries advocate for a development of a comprehensive and coherent set of standards as a basis for a legally binding instrument, while others express a preference for non-binding guidelines. The developing countries hold the former view, whereas the developed countries hold the latter view respectively.

The UN Declaration on the Right to Development (DRTD) is not a very clear document, and as a result, the content of the RTD has been the subject of many interpretations. Consequently, scholars from the south articulated the notion and enumerated the possible subjects and objects of the right, while jurists from the north questioned the existence of such right.

Another challenge is the use of language, especially as contained in the UN DRTD. The language of the Declaration is vague, imprecise and unclear in certain regard. This lack of clarity occasions a situation as to whether the individual is the subject or the beneficiary of the RTD. This situation creates sufficient jurisprudential confusion and vagueness, which is significantly reflected on the issues involving the justiciability of the RTD. The Declaration also fails to specifically mention the state as a subject of the RTD. ${ }^{14}$

Some Western scholars have argued that the RTD is a utopian right which feasibility is not realisable. This contention has received a sharp rebuke of prominent scholars, including Amartya Sen. Sen contends that feasibility must not and should not be a basis by which the cogency of human rights is measured when the objective itself is to work towards expanding the feasibility and full realisation of the right. Whether or not certain rights cannot be realised due to prevailing circumstances does not overrule them are rights. ${ }^{15}$

Another issue is the one of implementation of RTD. The implementation of the UN DRTD is the subject of an ongoing debate. By Resolution 1993/22 of the Commission a Working Group was recognised in 1993 for a period of three years. The workings of both groups have been found to be substantially the same. The reports of the 1993 Working Group has it that the main obstacles encountered at the international level in the implementation of RTD include: the negative effects of globalisation, heavy debt burden, financial conditionality by International Financial Corporation and decreasing aid flows, which have marginalised many developing countries; the inability of the international community, to set rules of institutions for co-operation in the international economic institutions. ${ }^{16}$

Another controversy has to do with who are the duty bearers in the various international RTD treaties. There are two perspectives in which to view this, that is: the international and the municipal level. At the international level, it could be said that there exist a general duty of co-operation between states. On the other hand, could it be said that the UN DRTD create a particular duty which the international community and developed states owe the developing states as explicitly

\footnotetext{
10 Article 22.

${ }^{11}$ Article 10.

12 Article 19.

${ }^{13}$ Okafor, O. C. 2008. 'Righting' the Right to Development: A Socio-Legal Analysis of Article 22 of the African Charter on Human and Peoples' Rights. In

Marks, S. P. (Ed.) Implementing the Right to Development: The Role of International Law. Geneva: Friedrich-Ebert-Stiftung. p. 55

${ }^{14} \mathrm{Iqbal}, \mathrm{K} .2007$. The Declaration on the Right to Development and Implementation. Political Perspectives. Vol. 1 (1) p. 12

15Tadeg, M. A. 2010. Reflections on the right to development: Challenges and prospects. African Human Right Law Journal. Vol. 10, No. 2325 - 344
}

${ }^{16} \mathrm{Iqbal}, \mathrm{K}$. op. cit. p. 20 
stated in Article 4(2) DRTD. The developing states have contended that the developed nations owe them a legally binding duty to extend foreign aids, grants, debt amnesty etc. to realise their right to development. They have justified their claim by arguing that the marginalisation the suffered as a result of slave trade and colonialism by most of these developed countries. On the other hand, their developed counterparts have argued that such legal duty does not exist and their assistance is only borne out of moral duty and concern for humanity.

Practical speaking, it is unclear to see how such an obligation could be defined and realised. For instance, how can one construe what is the most conducive international environment? This is another contested concept, which definition varies as development evolves from time to time. How can one ascribe blame for the failure to create such an environment? How can an individual, or state, hold a claim against the international community? And how can individual states, through bilateral activities, or as members of international organisations, assess whether they are adequately meeting their duty of international co-operation and creating the most conducive international environment? These are budding questions that beg for answers. ${ }^{17}$

The second perspective has to do with the duties of state to ensure their RTD at the municipal level. A state owe itself the duty to ensure and guarantee the right to development? If yes, to who is that duty owed? Can the citizens of a state demand and enforce such duty from the state where there is a failure of the state to so perform such obligation? These are other issues that crop up at this level.

Also there is no pronouncement by any national court in Africa in this regard. Similarly, the notion of the 'duties' enunciated in the Charter has remained vague, conferring no enforceable obligation on anyone. Over time these provision appears to be mere moral codes. ${ }^{18}$

Another challenge is on the justiciability of the RTD. Justiciability is the ability of courts to exercise jurisdiction to render decision on the basis of a legal obligation. A right is justiciable where it is established that it has given rise to a legally recognised cause of action within a jurisdiction. The UN DRTD does not create a legal cause of action. More so, the declaration is not binding on states. However, many of the elements of the right to development which we have examined earlier have been restated and reaffirmed in binding international law instruments, including international treaties, customary law and regional instruments such as the African Charter on Human and peoples' Right and other regional treaties which we have considered in this work. To that extent, it is argued that the RTD constitute a body of right that is recognised and enforceable at by international law.

\section{Prospects of the Right to Development}

The right to development is viewed as a third generation right. Initially, the activism for the international recognition of the RTD faced some stiff opposition. There was a subsequent consensus by nations of the world recognising such right. In 1993 the World Conference on Human Rights adopted the Vienna Declaration as a universal and inalienable right and an integral part of fundamental human rights'. However, there still exist disparity in the conceptualising and application of the right. The right has, thus, been more political in nature depending on the state involved.

Article 56 of the UN Declaration creates an obligation for all Member States to cooperate with the UN jointly and separately, 'for the achievement of the purposes set forth in Article 55. Article 55, in turn, commits the UN to the promotion of higher standards of living, full employment, and conditions of economic and social progress and development. As a resolution of the GA, the Declaration does not, on its own, have legally binding effect unless its individual articles can be said to reflect existing customary international law. At the same time, as a near unanimous resolution of the GA, the Declaration offers strong indication of the likely development of customary international law, and helps hasten that development. ${ }^{19}$ It is such that some scholars have even argued that it has crystallised into international customary law.

At the universal level, the RTD instruments are prevalently within the realm of international soft law. The implication is that most of those instruments are not of legally binding effect. Only the civil and political aspects of the RTD is a hard law. With more advocacy from developing states who are the supposed greater beneficiary of the right due to their developmental needs there may just a legally binding treaty recognising the economic, social and cultural aspect of the RTD.

At the regional and sub-regional level, there is plethora of internationally binding treaties. The question then is the issue of implementation and enforcement both at the regional and the municipal level. In Africa, for instance, there have been two instances where the RTD have been subjected to judicial interpretation. These were in the Ogoni and Endoroi Peoples' cases. This is a quite an achievement. However, the municipal implementation and accessibility to justice in exercise of the RTD has been disappointing. Despite the fact that African is in dire need of the exercise of the RTD, only few African countries like South Africa, recognises the RTD as a justiciable right in their Constitution. In Nigeria, for instance, Section 6(6) of the 1999 Constitution (as amended) pronounces the various strands of the RTD contained in chapter two of the constitution as non-justiciable. This has left a sour taste in the mouth of the people as it has led to several irresponsible governments that is not accountable to the people as their ability to approach the court to hold the government accountable to their having a good life is death on arrival. This is a situation of giving something with the left hand and taking it back with the right hand.

17Piron, L. H. 2002. The Right to Development: A Review of the Current State of the Debate for the Department for International Development. Right to Development Report. p. 13.

${ }^{18}$ Olowu, D. The United Nations human rights treaty system and the challenges of commitment and compliance in the South Pacific. Melbourne Journal of International Law Vol. 7. Retrieved on the $16^{\text {th }}$ February, 2018 from: law.unimelb.edu.au/_data/assets/pdf_file/0006/1681197/Olowu.pdf

${ }^{19}$ Davis, R. 2007. Summary of the UN Declaration on the Rights of Indigenous Peoples. p. 4. Retrieved on 16 th January, 2018 from: https://www.uts.edu.au/sites/default/files/JIHLBP8_11_07.pdf 


\section{Conclusion and Recommendations}

This work has examined the right to development; what it entails and its application thereof. It considered the various international instruments that recognise or even contemplate the RTD. The instruments exist in both the universal, regional and sub-regional instruments. Basically, we have assessed the extent to which States are individually and collectively taking steps to establish, promote and sustain national and international arrangements that create an enabling environment for the realisation of the right to development. In our view there are challenges which are common with these various instruments. These challenges, notwithstanding, there are prospects of better recognition and enforcement of these rights. The major challenges have been with the justiciability and enforceability of these rights. Hence, efforts must be heavily channelled towards this regard.

The RTD has to be regarded as a guarantor of the indivisibility of all human rights and a tool of reconciliation between artificially dislocated sets of norms, within and even beyond the human rights arena. Such recognition would call for coherent states' policies and obligations towards the enhancement of the indivisibility and universality of all human rights. The very essence of the RTD is straight, comprehensive and clear: it is the right to a national and international environment that enables or at least does not hinder the enjoyment by individuals and peoples of their basic human rights and fundamental freedoms, an environment that is free from structural and unfair obstacles to development'. 20 In view of the forgoing, we hereby make the following recommendations:

We align ourselves with the thoughts of Piron who is quoted as saying:

Developing countries governments need to be involved in discussions concerning rights-based approaches to development assistance. The Right to Development inter-governmental debate does not create such an opportunity as it is too politicised. But it would be important to hear from developing countries officials how they see their national development strategies as contributing to the realisation of human rights, and how this relates to the Right to Development. ${ }^{21}$

Governments of African countries must show sincerity with the actualisation of the right to development. This can be done by recognising and removing the legal roadblocks evident in their various municipal laws for the actualisation of the right by citizens of their countries. This is the first step before demanding for the collective duties of other nations in that regard. Where a government fails to be responsible to its people, no matter the amount of aid and assistance received from foreign nations, it would be an exercise in futility as it would be wasted by the same irresponsible government and the people will have no legal basis to enforce their RTD.

\section{References}

i. McInerney-Lankford, S. and Human, H. S. 2010. Rights Indicators in Development: An introduction. World Bank Study p. 66. Retrieved on the 16th January, 2018 From: siteresources.worldbank.org/EXTLAWJUSTICE/.../HumanRightsWP10_Final.pdf

ii. The Rio Declaration on Environment and Development (1992). Retrieved on the 16th January, 2018 from: www.unesco.org/education/pdf/RIO_E.PDF

iii. United Nations High Commissioner for Human Rights. 2016. Frequently Asked Questions on the Right to Development Fact Sheet No. 37. p. 5. Retrieved on 16th January, 2018

From: www.ohchr.org/Documents/Publications/FSheet37_RtD_EN.pdf

iv. Kingsbury B. 2011. Indigenous peoples. p. 15. Retrieved on 16th January, 2018 from: iilj.org/wpcontent/uploads/2016/08/Kingsbury-Indigenous-Peoples-1.pdf

v. Negro, D. M. 2008. Article 17 and Chapter VII of the revised OAS Charter and relevant experience of OAS institutions. In Marks, S. P. (Ed.) Implementing the Right to Development: The Role of International Law. Geneva: Friedrich-Ebert-Stiftung. p. 69.

vi. Okafor, O. C. 2008. "Righting" the Right to Development: A Socio-Legal Analysis of Article 22 of the African Charter on Human and Peoples' Rights. In Marks, S. P. (Ed.) Implementing the Right to Development: The Role of International Law. Geneva: Friedrich-Ebert-Stiftung.

vii. Iqbal, K. 2007. The Declaration on the Right to Development and Implementation. Political Perspectives. Vol. 1 (1) p. 12

viii. Tadeg, M. A. 2010. Reflections on the right to development: Challenges and prospects. African Human Right Law Journal. Vol. 10, No. 2325 - 344

ix. Piron, L. H. 2002. The Right to Development: A Review of the Current State of the Debate for the Department for International Development. Right to Development Report.

x. Olowu, D. The United Nations human rights treaty system and the challenges of commitment and compliance in the South Pacific. Melbourne Journal of International Law Vol. 7. Retrieved on the 16th February, 2018 from: law.unimelb.edu.au/_data/assets/pdf_file/0006/1681197/Olowu.pdf

xi. Davis, R. 2007. Summary of the UN Declaration on the Rights of Indigenous Peoples. p. 4. Retrieved on 16th January, 2018 from: https://www.uts.edu.au/sites/default/files/JIHLBP8_11_07.pdf

xii. Salama, I. 2008. The Right to Development: renewal and potential. In Marks, S. P. (Ed.) Implementing the Right to Development: The Role of International Law. Geneva: Friedrich-Ebert-Stiftung.

${ }^{20}$ Salama, I. 2008. The Right to Development: renewal and potential. In Marks, S. P. (Ed.) Implementing the Right to Development: The Role of International Law. Geneva: Friedrich-Ebert-Stiftung. p. 126 